cause of juvenile cataracts. Pediat. Res., 1: 14 (1967).

10. Hammerson, G. Levy, H. L., Frigoletto, F., and Mandell, R.: Comparison of galactose-1-phosphate uridyltransferase in fetal and adult tissues. Clin. Chim. Acta, 60: 281 (1975).

11. Kabacy, G., Hodgmann, J., Donnell, G. N., and Spears, R. L.: Galactose-1phosphate uridyl transferase levels in the newborn. Pediatrics, 38: 125 (1966).

12. Kalckar, H. M., Anderson, E. P., and Isselbacher, K. J.: Galactosemia, a congenital defect in a nucleotide transferase. Biochem. Biophys. Acta, 20: 262 (1956)

13. Kalckar, H. M., and Maxwell, E. S.: Bisynthesis and metabolic function of uridine diphosphoglucose in mammalian organisms and its relevance to certain inborn errors. Physiol. Rev., 38: 77 (1958).

14. Kirkmann, H. N., and Maxwell, E. S.: Enzymatic estimation of erythrocytic galactose-1-phosphate. J. Lab. Clin. Med., 56: 161 (1960)

15. Koo, C., Rogers, S., and Segal, S.: Developmental aspects of galactose-1phosphate uridyltransferase in rat intestine. Biol. Neonate, 27: 153 (1975).

16. Lermann, S.: Carbohydrate metabolism in the experimental galactose cataract. Nature, 184: 1406 (1959).

17. Lineweaver, H., and Burk, D.: The determination of enzyme dissociation constants. J. Amer. Chem. Soc., 56: 658 (1934).

18. Lowry, O. H., Rosebrough, N. J., Farr, A. L., and Randall, R. J.: Protein measurement with the Folin phenol reagent. J. Biol. Chem., 193: 265 (1951).

19. Mathai, C. K., and Beutler, E.: Biochemical characteristics of galactokinase from adult and fetal human red cells. Enzymologia, 33: 223 (1967).

20. Mellmann, W. J., and Tedesco, T. A.: An improved assay of erythrocyte and leukocyte galactose-1-phosphate uridyltransferase: Stabilization of the enzyme by a thiol protection reagent. J. Lab. Clin. Med., 66: 980 (1965).

21. Ng, W. G., Bergen, W. R., Donnell, G. N., and Spears, R. L.: Galactose-1phosphate uridyl transferase activity in hemolysates of newborn infants. Pediatrics, 39: 295 (1967).

22. Oliver, I. T.: Inhibitor studies on uridine diphosphoglucose pyrophosphorylase. Biochem. Biophys. Acta, 52: 75 (1961).
23. Osang, M., Shin-Buehring, Y. S., Wirtz, L., and Schaub, J.: Prenatal diagnosis of galactosemia. (Manuscript in preparation.)

24. Robinson, A. The assay of galactokinase and galactose-1-phosphate uridyltransferase. J. Exp. Med., 118: 359 (1963).

25. Segal, S., Rogers, S., and Holzapple, P. C.: Liver galactose-1-phosphate uridyl transferase: Activity in normal and galactosemic subjects. J. Clin. Invest., 50: 500 (1971).

26. Segal, S., and Roth, H.: Galactose metabolism by rat liver tissue: Influence of age. Science, 142: 1311 (1963).

27. Shin-Buehring, Y. S., Osang, M., Ziegler, R., and Schaub, J.: A method for galactose-1-phosphate uridyltransferase assay and the separation of its isozymes by DEAE-cellulose column chromatography. Clin. Chim. Acta, 70: 371 (1976).

28. Shin-Buehring, Y, S., Osang, M., Ziegler, R., and Schaub, J.: A simple assay for galactokinase using DEAE-cellulose column chromatography. Clin. Chim. Acta., 74: 1 (1977).

29. Sidbury, J. B.: Investigations and speculations on the pathogenesis of galactosemia. In: D. Y. Y. Hsia: Galactosemia, p. 13 (Charles C Thomas, Springfield, Ill., 1969).

30. Sidbury, J. B., and Gardner, L. I. (Editors): Molecular Genetics and Human Disease, p. 61 (Charles C Thomas, Springfield, Ill., 1960).

31. Stifel, F. B., Herman, R. H., and Rosenzweig, N. S.: Dietary regulation of galactose metabolizing enzymes: Adaptive changes in rat jejunum. Science, 162: 692 (1968)

32. Tedesco, T. A.: Human galactose-1-phosphate uridyltransferase. J. Biol. Chem., 247: 6631 (1972)

33. Tedesco, T. A., and Mellmann, W. T.: Galactosemia: Evidence for a structural gene mutation. Science, 122: 727 (1971).

34. This work was supported by Grant Scha $121 / 7$ of the Deutsche Forschungsgemeinschaft.

35. Requests for reprints should be addressed to: J. Schaub, M.D., Kinderklinik der Universität, Lindwurmstr. 4, D-8000 München 2 (West Germany).

36. Received for publication January 10,1977

37. Accepted for publication February 23, 1977

\title{
Lung Development in the Fetal Primate Macaca nemestrina. I. Growth and Compositional Changes
}

\author{
W. ALAN HODSON,"12) SUSAN PALMER, GERALD A. BLAKELY, JANET H. MURPHY, DAVID E. \\ WOODRUM, AND THOMAS E. MORGAN
}

Departments of Pediatrics and Medicine, the Regional Primate Research Center and the Child Development and Mental Retardation Center, University of Washington, Seattle, Washington, USA

\section{Summary}

This report relates lung growth and composition to body growth in 23 fetal and 2 newborn Macaca nemestrina (pigtail monkey) during the last third of gestation.

There was a linear relationship $(r=0.883)$ between gestational age and crown-rump length over the age range studied, and length increased by $1.18 \mathrm{~mm} / \mathrm{day}$. The average increment in body weight was $5.1 \mathrm{~g} /$ day.

Total lung weight increased in a manner similar to total body weight (wet lung weight $=1.91 \pm 0.44 \%$ of total body weight). Lung weight increased by $109 \mathrm{mg} /$ day until term. A correlation of 0.849 was observed between lung weight and gestational age. There was a linear increase in lung dry mass with increasing gestational age $(9 \mathrm{mg} / \mathrm{day}, r=0.701)$ and with increasing body weight $(1.38 \mathrm{mg} / \mathrm{g}$ body weight, $r=0.691)$. The dry weight of fetal lung accounted for $10.8 \pm 2.9 \%$ of total lung weight throughout the gestational period studied. Dry weight increased to $22-23 \%$ after birth.

There was a decrease in protein and DNA per $g$ wet weight of lung with advancing gestational age. Increases in total protein, DNA, and hemoglobin reflected the increasing size of the lung. Because gestational age is correlated with body size, body weight, and lung weight, total lung protein and total lung DNA should not provide any great advantage over total lung weight as a denominator for quantitative estimates of changing cell constituents with growth. Protein and DNA do not increase with gestational age when plotted per $g$ dry lung. DNA per $g$ dry lung tends to decrease with maturity, suggesting an increase in cell size.

\section{Speculation}

Whereas fetal lung growth is linearly related to body growth over the last third of gestation, both lung and body size show wide variance at any given age. Constituents of lung increase in a manner which varies from general lung or body growth and are 
best compared when expressed in relation to a common denominator such as a unit of lung dry weight.

This report relates changes in lung growth and composition to body growth in fetal $M$. nemestrina (pigtail monkey) during the last third of gestation. Lung weight, wet/dry weight ratio, protein, hemoglobin, and DNA composition were measured to provide fundamental data for subsequent studies correlating biochemical and ultrastructural development with physiologic function. This information should be useful in determining the appropriateness of the fetal or immature monkey for studies relevant to human clinical problems.

The lung structural studies of Boyden are the subject of a separate report (1) and demonstrate that the maturational process is comparable to that of the human fetus (2), proceeding through a pseudoglandular and a canalicular stage to a final phase of alveolar formation and development. Characterization of the compositional changes in the lung as alveolar development progresses is a prerequisite to quantitative and qualitative studies of surface active material. In addition, it should assist in determining the best denominator (e.g., DNA or dry lung) by which to compare quantitative changes in the lung with growth. The data, in combination with biochemical and physiologic changes (8), will be helpful in predicting the gestational age at which the $M$. nemestrina becomes viable and hence most susceptible to the development of hyaline membrane disease.

\section{MATERIALS AND METHODS}

Twenty-three fetal and two newborn monkeys were obtained as the result of timed matings of individually caged female $M$. nemestrina. Pregnancies were confirmed by digital examination 30 and 60 days after conception. Mothers were housed at the Regional Primate Research Center Field Station at the University of Washington (Medical Lake, Wash.). Pregnancies were terminated by uterotomy under ketamine-halothane anesthesia using aseptic technique. The gestational ages at the time of cesarian section ranged from 107-160 days. The fetuses were rapidly delivered, the umbilical cord clamped, and the airway obstructed to prevent air breathing. The fetus expired within a few minutes of delivery. The uterine incision was closed and the mother was returned to the breeding colony. The newborns were delivered spontaneously and killed at day 2 or 3 of postnatal life.

The fetus was weighed and the crown-rump length determined as the distance in millimeters from the crown of the skull to the base of the tail as the animal lay on its side with the head flexed. A tracheostomy was performed and the abdomen and chest were opened with a midline incision. A slight amount of fluid escaped from the trachea following incision. The lungs were removed en bloc with the heart and great vessels attached. The newborn infants were killed by intravenous pentobarbital, but otherwise the procedure was identical to that for the fetus. The weight of the en bloc dissection was taken and pressure-volume curves were determined as part of a separate study (8). Determination of pressure volume curves required 10-20 min. The lungs were then dissected free of the heart and great vessels and total lung weight was obtained. The lobes of the lung were quickly removed individually and weights were computed by the difference. Four slices of lung weighing $100-300 \mathrm{mg}$ each were taken from the inferior portion of the upper and lower lobe of each lung. They were immediately transferred into preweighed glass tubes and the weight measured to the nearest $0.1 \mathrm{mg}$. These lung slices were dried in a vacuum oven at $70^{\circ}$ until constant weight

Table 1. Individual and mean values for body size, lung size, and selected components of lung

\begin{tabular}{|c|c|c|c|c|c|c|c|c|c|}
\hline \multirow{2}{*}{\multicolumn{2}{|c|}{$\begin{array}{l}\text { Gestational } \\
\text { age, days }\end{array}$}} & \multirow[b]{2}{*}{ Sex } & \multirow[b]{2}{*}{$\begin{array}{c}\text { CR length, } \\
\mathrm{mm}\end{array}$} & \multirow[b]{2}{*}{ Body wt, g } & \multicolumn{5}{|c|}{ Lung } \\
\hline & & & & & & ry wt, $\mathrm{g}$ & $\begin{array}{l}\text { PNA, mg/g } \\
\text { dry }\end{array}$ & $\mathrm{Hb}, \mathrm{mg} / \mathrm{g}$ dry & $\mathrm{PC},{ }^{1} \mathrm{mg} / \mathrm{g}$ dry \\
\hline & 107 & $F$ & 150 & 199 & 3.36 & 0.375 & 66.1 & 37.1 & 41.1 \\
\hline & 108 & $\mathbf{M}$ & 140 & 185 & & 0.473 & 47.8 & 72.1 & 26.7 \\
\hline & 115 & $\mathrm{~F}$ & 137 & 192 & 4.69 & 0.496 & 80.6 & 68.5 & 36.3 \\
\hline & 120 & $\mathbf{M}$ & 165 & 211 & 5.08 & 0.652 & 82.7 & 82.2 & 27.1 \\
\hline & 122 & $F$ & 148 & 184 & 3.65 & 0.334 & 64.0 & 42.2 & 43.1 \\
\hline & 126 & $\mathbf{M}$ & 202 & 242 & 5.17 & 0.695 & 57.1 & 99.9 & 40.3 \\
\hline & 127 & $?$ & 169 & 242 & 5.53 & 0.866 & 35.2 & 78.5 & 30.9 \\
\hline & 130 & $\mathbf{M}$ & 178 & 289 & 5.45 & 0.594 & 58.4 & 101 & 31.5 \\
\hline & 135 & F & 183 & 335 & 5.67 & 0.644 & 47.3 & 123 & 52.1 \\
\hline & 139 & $M$ & 193 & 409 & 6.57 & 0.756 & 65.1 & 143 & 49.1 \\
\hline & 140 & $\mathrm{~F}$ & 171 & 262 & 4.30 & 0.527 & 63.6 & 111 & 56.5 \\
\hline & 142 & $\mathbf{M}$ & 195 & 411 & 7.99 & 0.766 & 67.1 & 55.7 & 73.4 \\
\hline & 145 & F & 186 & 407 & 5.72 & 0.673 & 58.9 & 163 & 49.7 \\
\hline & 145 & $\mathbf{F}$ & 190 & 388 & 7.28 & 0.757 & 56.6 & 105 & 65.6 \\
\hline & 149 & $F$ & 192 & 387 & 8.65 & 0.906 & 43.9 & 96.7 & 31.1 \\
\hline & 149 & $\mathrm{~F}$ & 183 & 326 & 6.53 & 0.620 & 68.3 & 153 & 80.8 \\
\hline & 149 & M & 190 & 466 & 9.32 & 0.946 & 41.1 & 84.7 & 39.2 \\
\hline & 153 & $\mathbf{M}$ & 200 & 379 & 5.85 & 0.634 & 53.7 & 142 & 70.9 \\
\hline & 154 & $?$ & 210 & 424 & 9.58 & 0.875 & 55.6 & 96.7 & 54.9 \\
\hline & 155 & M & 203 & 337 & 9.61 & 1.302 & 55.3 & 90.6 & 88.4 \\
\hline & 158 & $\mathrm{M}$ & 204 & 584 & 9.86 & 1.058 & 54.0 & 34.6 & 85.1 \\
\hline & 159 & $\mathrm{M}$ & 195 & 419 & 8.00 & 0.971 & 33.8 & 62.3 & 86.9 \\
\hline & 160 & $\mathbf{F}$ & 215 & 560 & 9.10 & 0.878 & 65.0 & 228 & 121. \\
\hline & 168 & $M$ & 219 & 479 & 4.60 & 1.042 & 51.0 & 150 & 124 \\
\hline & 168 & $\mathbf{M}$ & & 279 & 3.07 & 0.679 & 62.6 & 214 & 128 \\
\hline$n$ & 25 & & 24 & 25 & 25 & 25 & 25 & 25 & 25 \\
\hline $\bar{\chi}$ & 141 & & 184 & 344 & 6.32 & 0.741 & 57.4 & 105 & 61.3 \\
\hline SD & 18 & & 23 & 114 & 2.16 & 0.227 & 12.0 & 50 & 30.5 \\
\hline
\end{tabular}

${ }^{1}$ PC: phosphatidylcholine. For details of phospholipid analysis see Reference 8. 


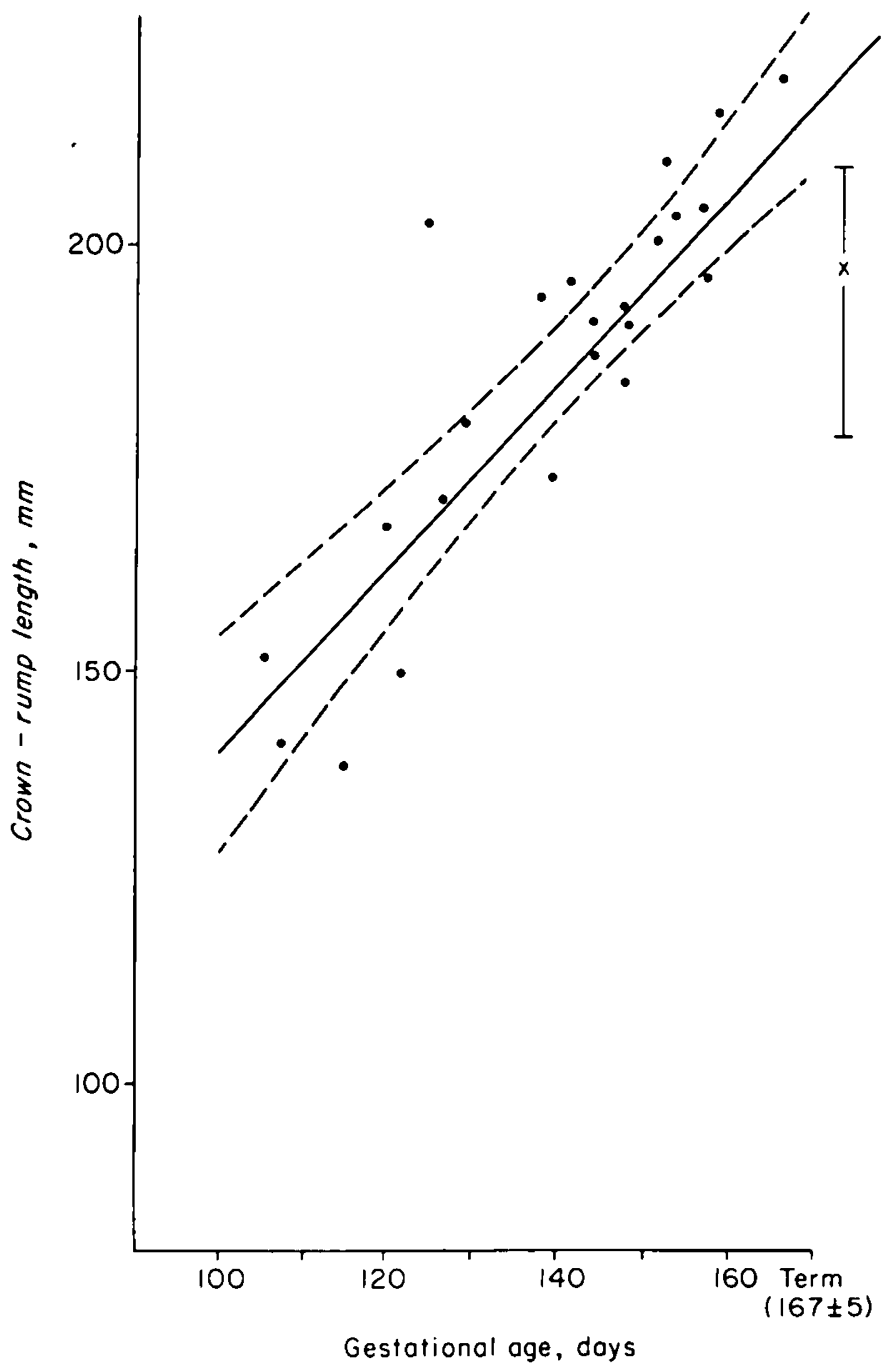

Fig. 1. Somatometry of the fetal $M$. nemestrina. The cross and bars represent the mean and range of newborn sitting heights reported by Sirianni et al. (10). Equation of line: crown-rump length $(\mathrm{mm})=1.18$ (gestational age in days) +18.7 . Dashed lines indicate $95 \%$ confidence intervals of the regression line.

was obtained on 2 consecutive days. The dry weight was determined and the dry/wet ratio computed as an average of duplicate determinations on each lung.

The lung remaining after removal of samples for dry/wet ratio on the right side was reweighed, chopped coarsely with scissors, and quantitatively transferred to a Duall glass tissue homogenizer. The samples were homogenized in $0.145 \mathrm{M} \mathrm{NaCl}, 0.01 \mathrm{M}$ Tris, and 0.001 M EDTA, pH 7.4. The left lung was weighed and homogenized separately. All operations were carried out at $0^{\circ}$ and volume was adjusted to $25 \mathrm{ml}$ with the homogenization solution.

Aliquots of the diluted lung homogenate were removed for the determination of total protein by the Lowry method (6), hemoglobulin using the Acculute hemoglobin method (7), and DNA using the reaction with diphenylamine in acetic acid (9).

\section{RESULTS}

The composite data for all animals including sex are given in Table 1. The crown-rump length was plotted against gestational age (Fig. 1). There was a linear relationship between gestational age and crown-rump length over the age range studied. Crownrump length increased $1.18 \mathrm{~mm} /$ day between 107 and 168 days. The correlation of length to age was 0.881 .
The average increment in body weight was $5.1 \mathrm{~g} /$ day (Fig. 2). There was a larger variation in body weight at term than earlier in gestation.

Data for total lung weight and composition are given in Table

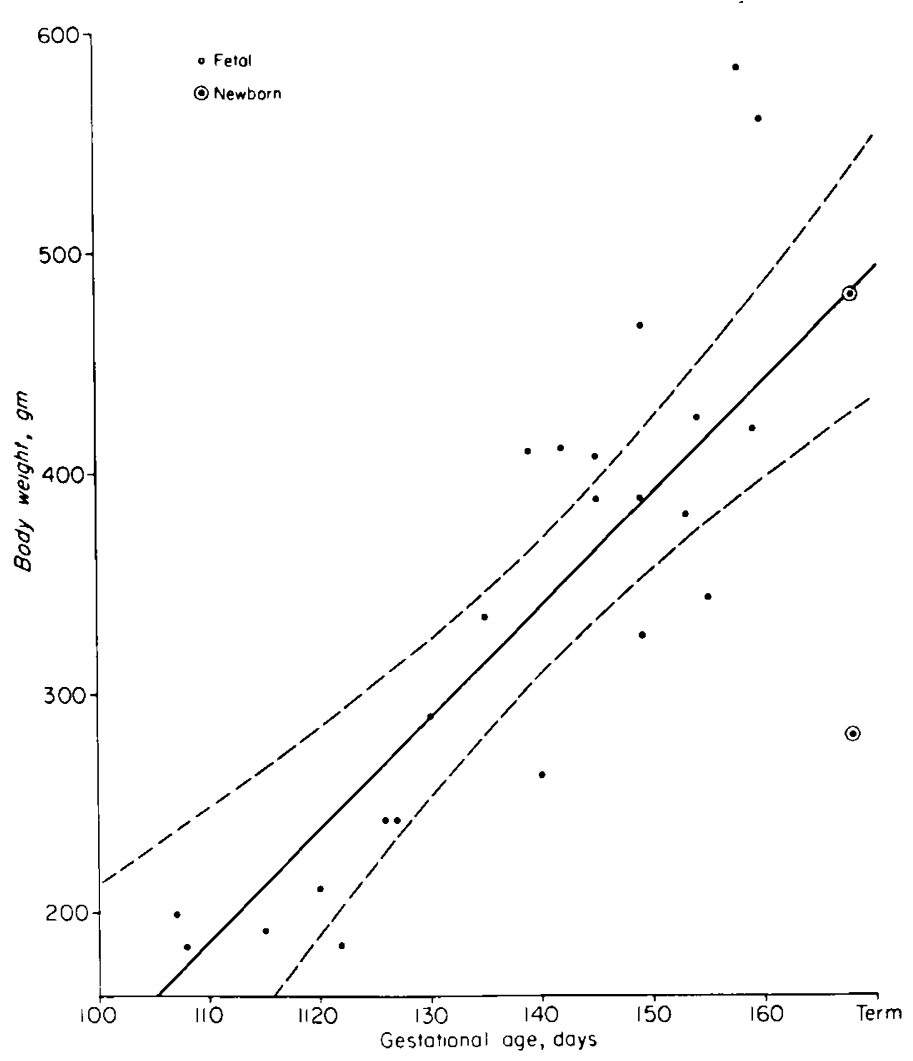

Fig. 2. Body weights of fetal $M$. nemestrina. Equation of line: body weight $(\mathrm{g})=5.08$ (gestational age in days) -372 .

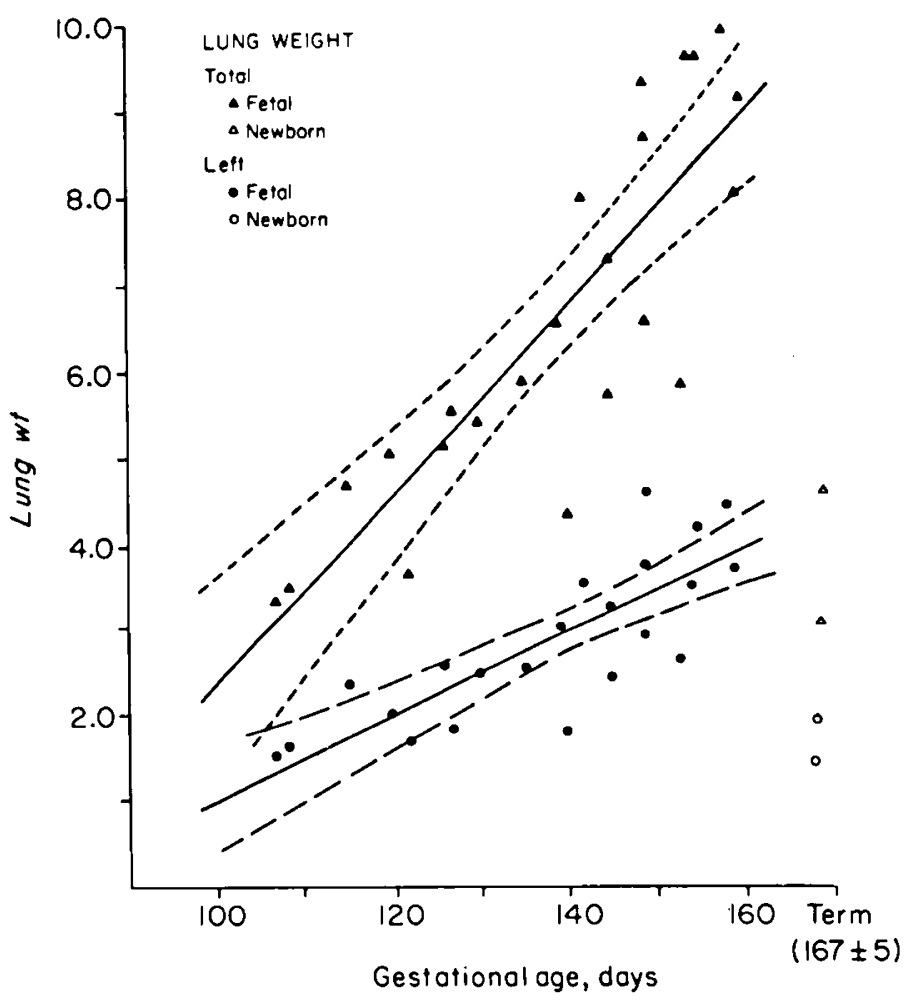

Fig. 3. Lung weights of fetal $M$. nemestrina. Equation of line: total lung weight $(\mathrm{g})=0.109$ (gestational age in days) -8.59 ; left lung weight $(\mathrm{g})=0.048($ age $)-3.81$. 


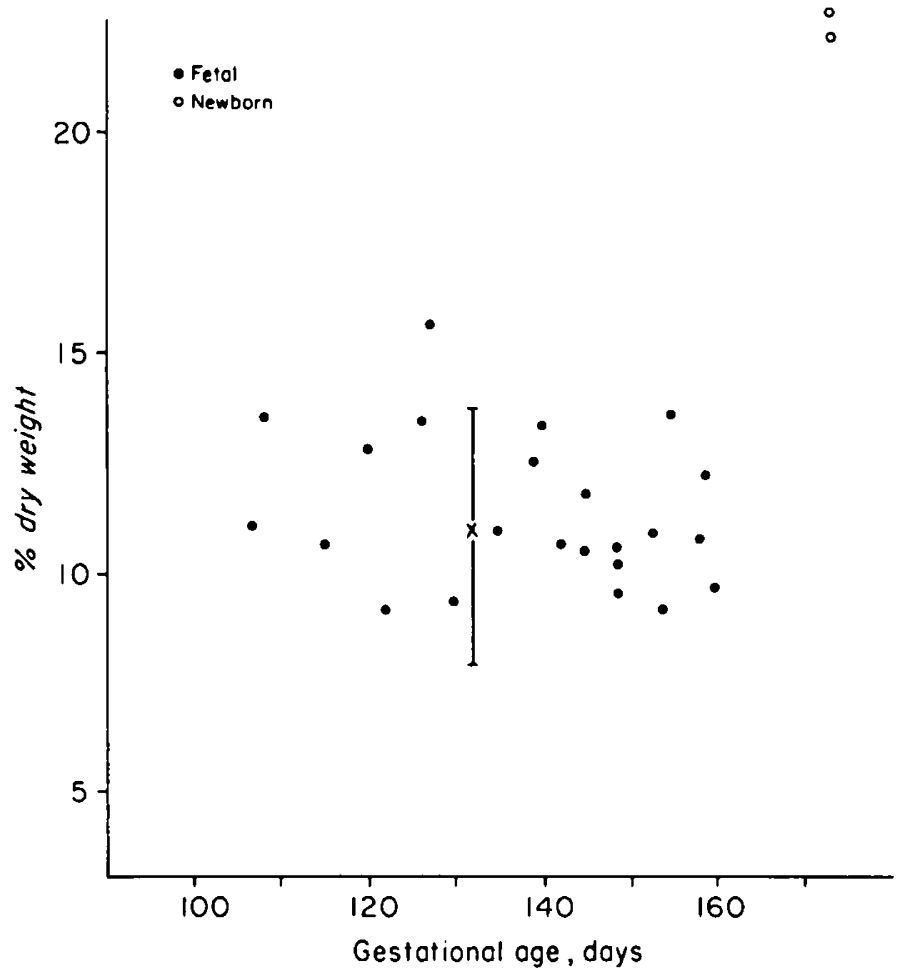

Fig. 4. Percent dry weights of fetal $M$. nemestrina lungs. The weight of lungs after prolonged vacuum dessication is expressed as a fraction of the total fresh weight. Cross and bar indicate mean and standard deviation of 23 observations.

1. Between 107 and 168 days lung weight increased $109 \mathrm{mg} /$ day until term and then decreased abruptly as the lungs became drier after birth (Fig. 3). A correlation of 0.849 was observed between total lung weight and gestational age during the fetal period. The right to left lung weight ratio varied from animal to animal with a mean of $1.29 \pm 0.22$. This ratio was not influenced by gestational age.

The dry weight percentage averaged $10.8 \%$ (range $8.8-$ $15.8 \%$, standard deviation $\pm 2.9 \%$ ) in fetal animals and increased to $22-23 \%$ in the newborn. Dry/wet lung weight ratios are expressed as percent of dry weight (dry weight/wet weight $\times 100)$ (Fig. 4).

There was a linear increase in lung dry mass with increasing gestational age (Fig. 5A) and with increasing body weight (Fig. $5 B$ ). Correlation coefficients of 0.701 and 0.694 , respectively, were observed.

Figure 6 presents data pertaining to the total lung content of protein, hemoglobin, and DNA, also expressed in terms of milligrams per $\mathrm{g}$ dry weight and milligrams per $\mathrm{g}$ wet weight of lung. The increase in the total values are a reflection of the increasing size of the lung. Protein, when expressed in terms of a unit of lung weight, does not change with advancing gestational age. Hemoglobin, however, does appear to increase during the period studied. DNA appears to decrease, although there is great variability throughout gestation.

\section{DISCUSSION}

Data obtained in this study are in close agreement with crownrump (C-R) and body weight data for the newborn of this species previously reported by Sirianni et al. (10). However, our measurements of C-R length at term were consistently greater. Sirianni and associates measured the sitting height of living animals; whereas we obtained crown-rump length postmortem in the lateral position with the neck flexed. Therefore, the difference in the two reports may be explained by the natural compression due to gravity and muscular forces of the sitting, living animal.

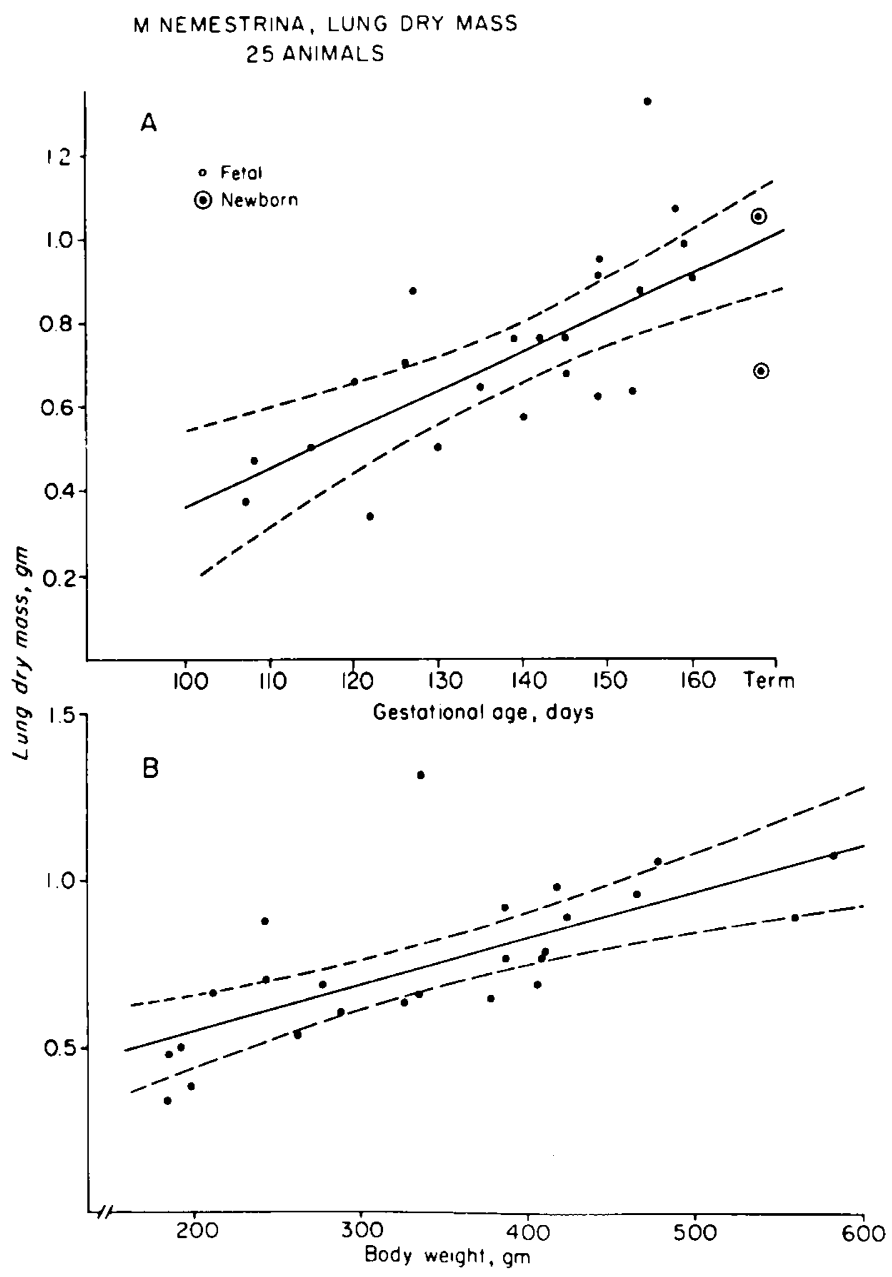

Fig. 5. Total lung dry weight (lung dry mass) as a function of gestational age $(A)$ and body weight $(B)$. Lung dry mass is the product of lung wet weight and percentage of dry weight determined for left and right lungs separately. Equations of lines: $(A)$ lung dry mass $(\mathrm{g})=$ 0.0090 (gestational age in days) $-0.53 ;(B)$ lung dry mass $=0.00138$ (body weight in grams) plus 0.268 .

The variations in C-R length $( \pm 24 \mathrm{~mm}$ at the $95 \%$ confidence level) are too great to estimate gestational age in untimed fetuses to within less than \pm 18 days at the $95 \%$ confidence level, therefore timed fetuses are required for most developmental studies. Body weight as a function of gestation was more variable than anticipated. Newborn weights were comparable to the data of Sirianni et al. (10). Male-female variations may have accounted for weight variance (5). Although the plots of crown-rump lengths and body weights against gestational age are represented as straight-line functions, it is quite likely that the curve is actually sigmoidal with a lower rate of increase as the animal approaches the end of gestation.

Although body weight was variable, total lung weight increased in a manner similar to total body weight, resulting in a ratio of lung weight to body weight which was quite constant (wet lung weight $=1.91 \pm 0.44 \%$ of total body weight). This constant lung weight proportion suggests that lung development depends most closely on total fetal body weight and, thus, on overall fetal development.

A subject of considerable interest in many fetal studies has been the water content of lung tissue. Brumley et al. (3) found that the ovine fetal lung became drier from 70 to about 110 days of gestation and then wetter during the last 30 days of gestation. In our studies, variation in lung water content was unrelated to gestational age. The fetal lungs remained relatively wet until birth. The increase in percentage of dry weight after birth is 

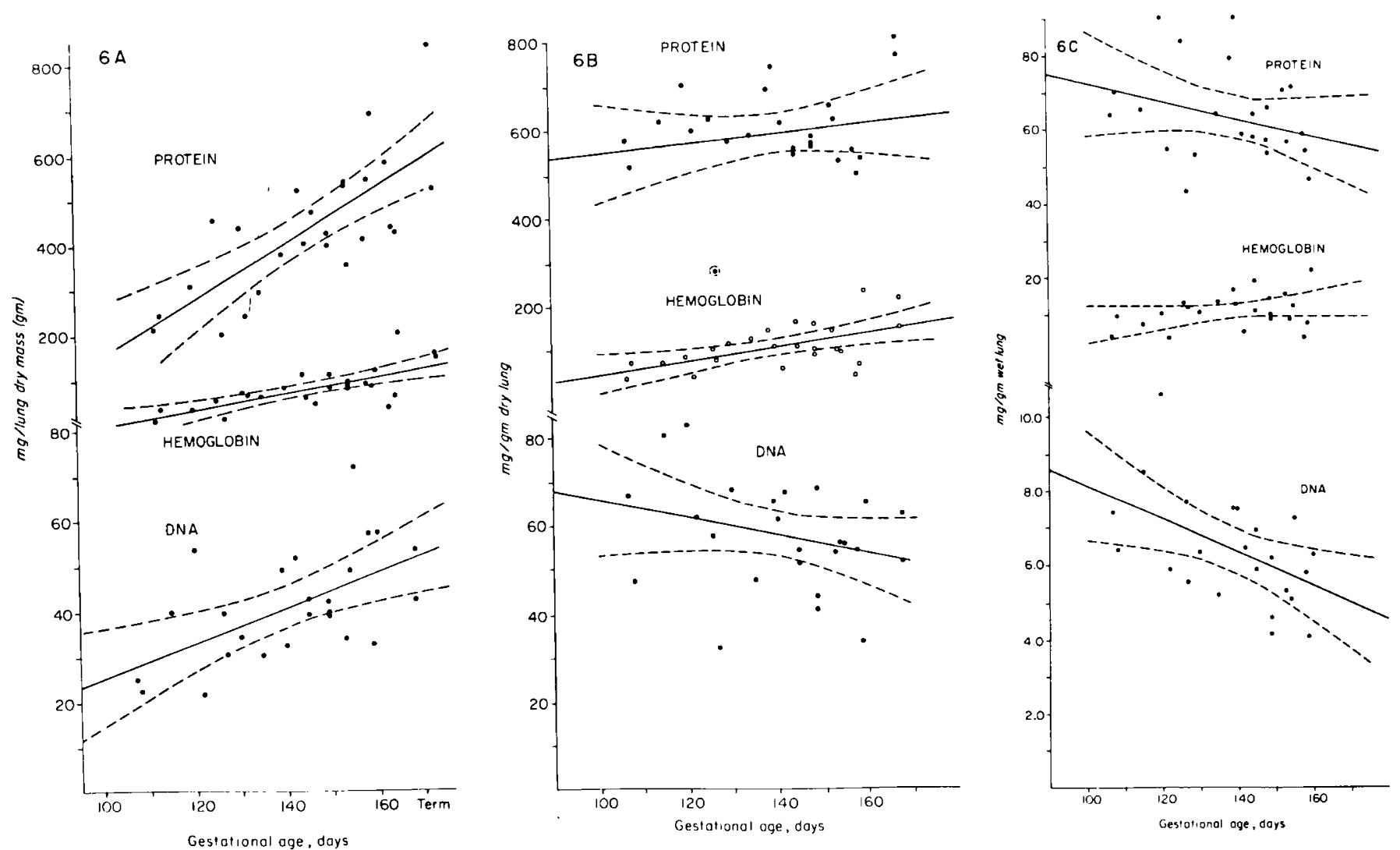

Fig. 6. Relationships of lung protein, hemoglobin, and DNA: $(A)$ per lung dry mass, $r$ values for protein $=0.74$, for $\mathrm{Hb}=0.71$, and for DNA $=$ $0.56 ;(B)$ per g dry lung, $r$ values for protein $=0.17$, for $\mathrm{Hb}=0.53$, and for $\mathrm{DNA}=0.30 ;(C)$ per $\mathrm{g}$ wet lung, $r$ values for protein $=0.29$, for $\mathrm{Hb}=$ $0: 32$, and for DNA $=0.50$.

attributed to absorption of fetal intra-alveolar fluid. Studies of water content in fetal rhesus monkey lungs (4) show little change from 75 days gestation to term and are consistent with our results.

Because the lung is highly vascular, consists of a relatively large number of tissue and cell types and contains much fluid during the fetal stages of development, the designation of the optimal denominator upon which to base concentration values for tissue constituents (e.g., surfactant) has been a persistent problem. Concentration may be based upon units of wet weight, dry weight, or protein. Alternatively, some parameter of cell number (e.g., DNA), may serve as a constant index. Attempts have also been made to correct protein or weight determinations for the blood content of lung by assessing hemoglobin content.

A unit of wet weight seems least desirable as a common denominator since $85-90 \%$ of the fetal lung is water, and evaporative loss occurs rapidly after expiration. Variation in lung wet/ dry ratios seen in our animals (Figure 4 ) may be due to several factors. Evaporative losses would be greater in the less mature and smaller lungs due to a greater external surface area per lung mass. Not all lungs were weighed at precisely the same time after extirpation, possibly resulting in differences in the amount of evaporative loss. The tissue sample size for wet/dry determination was somewhat smaller in young animals in order to conserve sufficient tissue for other analyses, and this would tend to magnify any weighing errors. There is a decrease in protein and DNA per g wet weight with advancing gestational age (Fig. $6 \mathrm{~A}$ ), which may be due to a real increase in percentage of water or to an apparent increase due to methodology. The scatter of wet/dry ratios (Fig. 4) does not permit a more precise analysis of this problem.

There is a linear relationship of total lung protein, hemoglobin, and DNA to gestational age (Fig. $6 A$ ). Since gestational age also correlates with body size, body weight, and lung weight, total lung protein and total lung DNA should not provide any

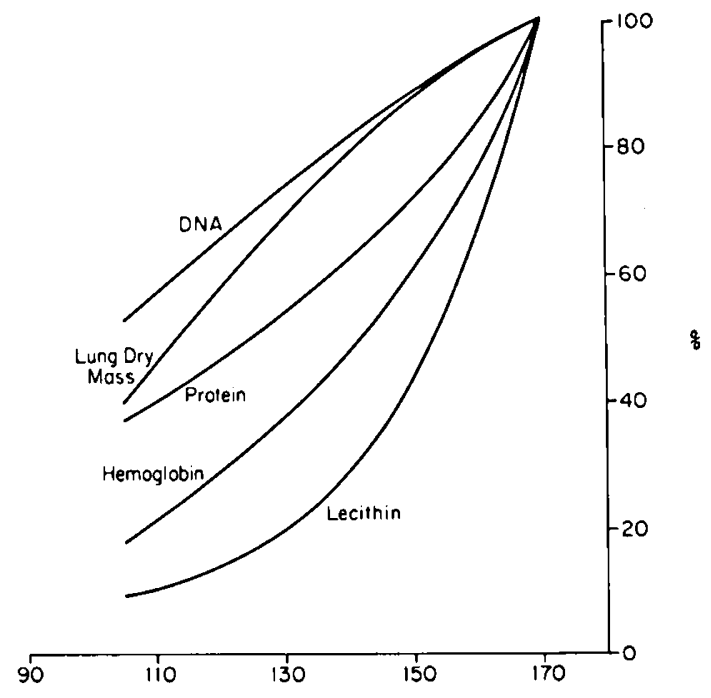

Gestational age, days

Fig. 7. Plots of the percentage of value of lung components during late gestation against gestational age $(100 \%$ is the calculated value for 170 days of gestational age). The regression lines were fitted by the method of the least squares to the equation $y=a+b_{1}(a g e)+b_{2}(a g e)^{(s)}$ from the data in Table 1.

great advantage over total lung weight as a denominator for quantitative estimates of changing cell constituents with growth.

Protein and DNA do not increase with gestational age when plotted per g dry lung (Fig. 6B). DNA tends to decrease with maturity, suggesting an increase in cell size. The scatter in the 
DNA measurement probably reflects methodologic errors rather than true variation. For this reason DNA as measured by the Schneider technique (9) would not provide the most accurate denominator for cellular changes.

Hemoglobin concentration increases gradually during gestation whether measured per $g$ wet or per $g$ dry lung tissue. Vascularization (capillarization) begins at about 80 days in these fetuses (1) and the vascular channels and blood content should increase.

None of the concentration units discussed above is entirely satisfactory; therefore, we have shown each value in relationship to commonly used denominators (Fig. 6). An expression of these complex relationships between 107 and 168 days gestation is shown in Figure 7 . The relationships suggest that DNA, and thus perhaps cell number, increases linearly and begins to level off in late gestation. In contrast, lecithin, an important constituent of cell membranes, rises exponentially (8). We conclude from the relationships in Figures 6 and 7 that components of the developing lung increase at varying rates. Because the data from which Figure 7 has been drawn are variable one should interpret this figure with caution. Particularly, it should be emphasized that there is no single satisfactory predictor of any component of maturing fetal lung. The variance due to lung water content and its loss in experimental studies must be taken into account. Therefore, we favor the use of dry weight measurements and, for some purposes, lung dry mass (the total dry mass of lung at a given gestational age), particularly when extracellular lung composition might be altered by variations in lung water content such as in pulmonary edema.

\section{CONCLUSION}

Compositional changes in the lungs of 23 fetal and 2 newborn monkeys ( $M$. nemestrina) have been measured throughout the latter part of gestation. Gestational ages at time of cesarian section and death ranged from 107 to 168 days (term). Body weight, crown-rump length, and lung weight all increased in relation to advancing gestational age. The dry weight of the fetal lung accounts for $10.8 \pm 2.9 \%$ of the total weight and does not change significantly with gestational age. Dry weight increased to $22-23 \%$ in the newborn. Increases in protein, DNA, and hemoglobin reflect increases in the size of the lung; however, protein, when expressed per unit of lung weight or body weight, does not increase with age. The hemoglobin content increases gradually, presumably commensurate with an increase in vascularization of the lung. DNA content per $g$ dry lung decreases slightly with age. This suggests that cell size is increasing at a more rapid rate than cell number. It is suggested that lung tissue components are most accurately expressed with reference to a unit of dry lung weight.

\section{REFERENCES AND NOTES}

1. Boyden, E. A.: The development of the lung in the pigtail monkey (Macaca nemestrina, L.). Anat. Rec., 186: 15 (1976).

2. Boyden, E. A.: The mode of origin of pulmonary acini and respiratory bronchioles in the fetal lung. Amer. J. Anat., 141: 317 (1974).

3. Brumley, G. W., Chernick, V., Hodson, W. A., Normand, C., Fenner, A., and Avery, M. E.: Correlations of mechanical stability, morphology, pulmonary surfactant and phospholipid in the developing lamb lung. J. Clin. Invest., 46: 863 (1967).

4. Kerr, G. R., Campbell, J. A., Helmuth, A. C., and Waisman, H. A.: Growth and development of the fetal rhesus monkey (Macaca mulatta). I1. Total nitrogen, protein, lipid, glycogen and water composition of major organs. Pediat. Res., 5: 151 (1971).

5. Kerr, G. R., Kennan, A. L., Waisman, H. A., and Allen, J. R.: Growth and development of the fetal rhesus monkey. I. Physical growth. Growth, 33: 201 (1969).

6. Lowry, O. H., Rosebrough, N. J., Farr, A. L., and Randall, R. J.: Protein measurement with the Folin phenol reagent. J. Biol. Chem., 193: 265 (1951).

7. Acculate Cyanmethemoglobin Analysis Kit. Ortho Diagnostics, Ortho, Raritan, N.J.

8. Palmer, S., Morgan, T. E., Prueitt, J. L., Murphy, J., and Hodson, W. A.: Lung development in the fetal primate, Macaca nemestrina. II. Pressurevolume and phospholipid changes. Pediat. Res., 11: 1015 (1977).

9. Schneider, W. C.: Determination of nucleic acids in tissues by pentose analysis. Methods in Enzymology, Vol. 3, p. 680 (Academic Press, New York, 1957).

10. Sirianni, J. E., Swindler, D. R., and Tarrant, L. H.: Somatometry of newborn Macaca nemestrina. Folia Primatol., 24: 16 (1975).

11. This research was supported by Grants HD-02354, HD-0057, HD-00747, RR-00166, and Pulmonary SCOR HL-14152 from the National Institutes of Health.

12. Requests for reprints should be addressed to: W. A. Hodson, M.D., Department of Pediatrics, University of Washington, Seattle, Wash. 98195 (USA).

13. Received for publication October $21,1976$.

14. Accepted for publication February 23, 1977. 